\title{
Alterations in antioxidant metabolism in coffee leaves infected by Cercospora coffeicola
}

\author{
Alterações no metabolismo antioxidante de folhas de \\ cafeeiro infectadas por Cercospora coffeicola \\ Camila Cristina Lage de Andrade ${ }^{\mathrm{I}^{*}}$ Rayssa Pereira Vicentin ${ }^{\mathrm{II}}$ Josineide Rodrigues Costa ${ }^{\mathrm{III}}$ \\ Fabiano José Perina ${ }^{I V}$ Mario Lúcio Vilela de Resende ${ }^{I}$ Eduardo Alves ${ }^{I}$
}

\section{ABSTRACT}

Brown eye spot (BE) caused by Cercospora coffeicola is the main disease of coffee crop. A variation in symptoms of BE has been reported in the field, raising suspicion of occurrence of new species. However, information about coffee-C. coffeicola interaction is still limited. This research aimed to determine the difference between antioxidant metabolism of coffee plants cultivar Mundo Novo inoculated with a strain isolated from a common BE lesion (CML 2984) and a strain isolated from a black BE lesion (CML 2985). The enzyme activity of peroxidase (POX), catalase (CAT), superoxide dismutase $(S O D)$, ascorbate peroxidase $(A P X)$ and phenylalanine ammonia lyase (PAL) were determined. Activities of POX, APX, and PAL increased in plants inoculated with both strains compared to noninoculated plants at 12 and 24 hours post inoculation (hpi). CAT activity increased in inoculated plants with black BE strain at 24 hpi and both strains at 48 hpi. The SOD activity only increased in inoculated plants with both strains at 48 hpi. These results show that an elevated antioxidant response was observed when the plants were challenged with both strains of $\boldsymbol{C}$. coffeicola. Both strains produced lesions of the common type, suggesting that other factors lead to the development of black BE lesion type under field conditions and further investigation is needed.

Key words: Coffea arabica L., "common" brown eye spot, "black" brown eye spot, reactive oxygen species.

\section{RESUMO}

A cercosporiose, causada pelo fungo Cercospora coffeicola, é uma das principais doenças que afeta o cafeeiro. Uma variação nos sintomas de cercosporiose foi encontrada no campo, levantando suspeitas da ocorrência de uma nova espécie. Considerando que informações sobre a interação cafeeiro-C. coffeicola ainda são limitadas, objetivou-se, neste trabalho, determinar diferenças no metabolismo oxidativo de plantas de cafeeiro, cultivar 'Mundo Novo', inoculadas com isolado proveniente de lesões de cercosporiose do tipo olho pardo (CML 2984) e isolado proveniente de lesões de cercosporiose do tipo negra (CML 2985). Foram determinadas a atividade das enzimas peroxidase (POX), catalase (CAT), superóxido dismutase (SOD), ascorbato peroxidase (APX) e fenilalanina amônia liase (PAL). As atividades das enzimas $P O X, A P X$ e PAL aumentaram nas plantas inoculadas com ambos os isolados, quando comparadas com as plantas não inoculadas às 12 e 24 horas após inoculação (hai). A atividade da CAT aumentou nas plantas inoculadas com o isolado que causa sintomas de cercosporiose do tipo negra às 24 hai e, para ambos os isolados, às 48 hai. Plantas inoculadas com ambos os isolados demonstraram aumento na atividade da SOD somente às 48 hai. Este estudo mostrou que uma resposta antioxidante elevada foi observada quando as plantas foram inoculadas com os dois isolados de C. coffeicola. Ambos os isolados produziram lesões de cercosporiose do tipo comum, sugerindo que outros fatores que causam lesões de cercosporiose do tipo negra ainda necessitam ser investigados.

Palavras chave: Coffea arabica L., cercosporiose do tipo olho pardo, cercosporiose do tipo negra, espécies reativas de oxigênio.

\section{INTRODUCTION}

Brown eye spot (BE) caused by the fungus Cercospora coffeicola Berkeley \& Cooke, is one of the main diseases of coffee trees (Coffea arabica L.), causing reduced yield and quality of the beverage (LIMA et al., 2012). Observed symptoms can vary under field conditions, resulting in several speculations and

IDepartamento de Fitopatologia, Universidade Federal de Lavras (UFLA), Campus Universitário, CP 3037, 37200-000, Lavras, MG, Brasil. E-mail: camilalage86@gmail.com. "Corresponding author.

${ }^{I}$ Departamento de Biologia/Microbiologia, Universidade Federal de Lavras (UFLA), Lavras, MG, Brasil.

IIIDepartamento de Química, Universidade Federal de Lavras (UFLA), Lavras, MG, Brasil.

${ }^{\mathrm{IV}}$ Empresa Brasileira de Pesquisa Agropecuária, Embrapa Algodão, Campina Grande, PB, Brasil. Received 06.27.15 Approved 04.12.16 Returned by the author 06.13.16 CR-2015-0938.R2 
hypotheses such as the possibility of genetic variation in the pathogen and different environmental and nutritional effects (phosphorus deficiency, nitrogen and potassium) (NELSON, 2008; MATIELLO \& ALMEIDA, 2013). Typical symptoms on coffee leaves due to infection by C. coffeicola are small necrotic spots consisting of a light-colored center surrounded by a purple brown ring with yellow edges, giving rise to the name common BE. The atypical symptom is characterized by black BE lesions which are larger than normal and resembled leaf spot (MATIELLO \& ALMEIDA, 2013). It is known that Cercospora produces a toxin called cercosporin which causes damage to the cellular membrane of the host in the presence of sunlight, resulting in lipid peroxidation, loss of electrolytes and formation of reactive oxygen species (ROS) (SHARMA et al., 2012; DAUB et al., 2013). In order to minimize damage caused by this oxidative stress, plants developed mechanisms of enzymatic and non-enzymatic defence (SCANDALIOS, 2005). Peroxidase (POX), catalase (CAT), superoxide dismutase (SOD), ascorbate peroxidase (APX), glutathione-S-transferase (GST), glutathione redutase (GR), phenylaline ammonia lyase (PAL) and glutathione peroxidase (GPX) are among the enzymes used in enzymatic defence (SHARMA et al., 2012).

Previously conducted research reported changes in the defense system antioxidant of the plants in response to induced stress by biotic and abiotic agents (DEBONA et al., 2012; NASCIMENTO et al., 2014; DOMICIANO et al., 2015). It is unknown whether the coffee plant responds in a different way to $\boldsymbol{C}$. coffeicola strains causing the two distinct BE symptoms (common $\mathrm{BE}$ and black BE). Considering the significant differences in the host biochemical response, it can be useful as an indirect indicator of the existence of genetic variability among the strains that cause distinct symptoms. Considering this, the aim of this research was to investigate whether the alterations in the oxidant metabolism of coffee leaves is similarly induced by the two $C$. coffeicola strains from the typical common $\mathrm{BE}$ and the atypical black BE symptoms. Effects of different strains on coffee can be measured and used as an indicator for what strain is affecting the coffee, eg, a biomarker. This is essential to research, especially those related to epidemiology and management strategies including resistance and chemical control.

\section{MATERIALS AND METHODS}

Plant material and growth conditions

Six-month-old Coffea arabica seedlings

from cultivar 'Mundo Novo 376/4', susceptible to

C. coffeicola, were used in all experiments. Plants were grown under controlled temperature $\left(21 \pm 2^{\circ} \mathrm{C}\right)$ and 12 hours photoperiod.

Fungal strains and inoculum preparation

Two C. coffeicola strains were used in this research. Strain CML 2984 and CML 2985 were selected from a collection of strains previously isolated from coffee leaves collected from various locations in Brazil. Strain CML 2984 was isolated from a common BE lesion in a field located in Bonfinopolis, Minas Gerais, Brazil and will be referred to as 'common BE' from now on; strain CML 2985 was isolated from a black type BE lesion collected from a coffee field in Tres Pontas, Minas Gerais, Brazil.

Induction of in vitro sporulation of $\boldsymbol{C}$. coffeicola was performed by following the method developed by SOUZA et al. (2011). Briefly, six disks ( $5 \mathrm{~mm}$ in diameter) were removed from the border of the medium containing the mycelial growth and transferred to a $25 \mathrm{~mL}$ flask containing $10 \mathrm{~mL}$ of $\mathrm{V} 8$ medium (10\% tomato juice V8). They were kept in a shaker at $25^{\circ} \mathrm{C}$ with $110 \mathrm{rpm}$ for four days. Fungal growth of each flask was poured into Petri dishes containing $1.5 \%$ water agar medium. These plates were kept open in an incubator at $40 \mathrm{~cm}$ from the light bulbs with 12 hours photoperiod and $25^{\circ} \mathrm{C}$. This dehydration process is used for the induction of sporulation in $\boldsymbol{C}$. coffeicola (SOUZA et al., 2011). After five days, an aliquot of $10 \mathrm{~mL}$ of distilled water was added to each Petri dish and the colony was scraped with a glass rod, and the spore suspension was filtered through cheese cloth. The concentration of conidial suspension used was adjusted to $8.25 \times 10^{4}$ conidia $\mathrm{mL}^{-1}$ for both strains. Temperature and relative humidity were daily assessed using the datalogger (HT-500, Instrutherm, Sao Paulo, Brazil).

Determination of the activities of enzymes involved in the oxidant metabolism

Samples of the first and second pair of leaves from the apex to the base (total of 6 leaves through repetition of each treatment) were collected at $12,24,36$ and 48 hours post inoculation (hpi). Samples were individually stored in aluminum foil, immediately flash frozen in liquid nitrogen $\left(\mathrm{N}_{2}\right)$ and stored at $-80^{\circ} \mathrm{C}$ until further analysis. To determine the activities of POX (EC 1.11.1.7) and PAL (EC 4.3.1.5), $0.2 \mathrm{~g}$ of leaf tissue were macerated in a mortar and pestle containing liquid $\mathrm{N}_{2}$ and $1 \%(\mathrm{w} /$ vol) polyvinylpyrrolidone (PVP) to obtain a fine powder. The powder was homogenized in $1.5 \mathrm{~mL}$ of sodium phosphate buffer $50 \mathrm{mM}(\mathrm{pH} 6.5)$ containing 
$1 \mathrm{mM}$ phenylmethyl sulfonic fluoride (PMSF) and centrifuged at $13,000 \times \mathrm{g}$ for $25 \mathrm{~min}$ at $4^{\circ} \mathrm{C}$. Supernatant was used to determine enzyme activity.

POX activity was determinated following the method of KAR \& MISHRA (1976). A mixture of $80 \mu \mathrm{L}$ potassium phosphate buffer $100 \mathrm{mM}$ $(\mathrm{pH} 7.0), 40 \mu \mathrm{L}$ of pyrogallol $50 \mathrm{mM}$ and $40 \mu \mathrm{L}$ of hydrogen peroxide $125 \mathrm{mM}$ was added to $40 \mu \mathrm{L}$ of extract. Absorbance was measured at $420 \mathrm{~nm}$ in a Gen5 $^{\mathrm{TM}}$ spectrophotometer $\left(\right.$ BioTek $^{\circledR}$ Instruments, Winooski, USA). The coefficient of molar extinction of $2.47 \mathrm{mM}^{-1} \mathrm{~cm}^{-1}$ was used to calculate POX activity (CHANCE \& MAEHLEY, 1955), which was expressed in $\mathrm{mM}$ of purpurogallin produced by $\mathrm{min}^{-1} \mathrm{mg}^{-1}$ of protein. Enzyme activity of PAL was analyzed by using the modified method of GUO et al (2007) where $5 \mu \mathrm{L}$ of the extract is added to a mixture containing $145 \mu \mathrm{L}$ of Tris-HCl buffer $50 \mathrm{mM}$ (pH 8.8) and $50 \mu \mathrm{L}$ of $50 \mathrm{mM} L$-phenylalanine. Absorbance of the trans-cinnamic acid derivatives was measured in a Gen $5^{\mathrm{TM}}$ spectrophotometer at $290 \mathrm{~nm}$ and the coefficient of molar extinction of $10^{4} \mathrm{~m} \mathrm{M}^{-1} \mathrm{~cm}^{-1}$ (ZUCKER, 1965) was used to calculate PAL activity (in $\mu \mathrm{M} \mathrm{min} \mathrm{mg}^{-1}$ of protein).

To obtain the extract for enzymatic determination of CAT (EC 1.11.1.6), SOD (EC 1.15.1.1) and APX (E 1.11.1.11), 0.2g of leaf fragments were macerated as described above. The powder obtained was homogenized in $1.5 \mathrm{~mL}$ of potassium phosphate buffer $400 \mathrm{mM}(\mathrm{pH} 7.8)$ containing EDTA $10 \mathrm{mM}$, ascorbic acid $200 \mathrm{mM}$ and PVP $1 \%\left(\mathrm{wt} \mathrm{vol}{ }^{-1}\right)$. The homogenate was centrifuged as described previously. CAT activity was determined through the method of CAKMAK \& MARSCHNER (1991) where the reaction mixture was composed of potassium phosphate buffer $200 \mathrm{mM}(\mathrm{pH} \mathrm{7.0)}$, distilled water and hydrogen peroxide $250 \mathrm{mM}$. The reaction was initiated after the addition of $10 \mu \mathrm{L}$ of the crude enzyme extract, and the activity was determined by the rate of $\mathrm{H}_{2} \mathrm{O}_{2}$ decomposition at $240 \mathrm{~nm}$ for 3 minutes at $25^{\circ} \mathrm{C}$. Coefficient of molar extinction of $36 \mathrm{M}^{-1} \mathrm{~cm}^{-1}$ (ANDERSON et al., 1995) was used to calculate CAT activity $\left(\mathrm{mM} \mathrm{min} \mathrm{mg}^{-1} \mathrm{mg}^{-1}\right.$ of protein). SOD activity was determined by adding $30 \mu \mathrm{L}$ of leaf extract in $170 \mu \mathrm{L}$ of reaction mixture composed of potassium phophate buffer $100 \mathrm{mM}$ ( $\mathrm{pH} 7.8$ ), methionine $70 \mathrm{mM}, p$-nitrotetrazole blue (NBT) $1 \mathrm{mM}$, EDTA $10 \mu \mathrm{m}$ and riboflavin $0.2 \mathrm{mM}$. The reaction occurred at $25^{\circ} \mathrm{C}$ under lighting lamps of $15 \mathrm{~W}$. After $10 \mathrm{~min}$ of light exposure, the light was interrupted and the production of formazan blue due to the photo reduction of NTB was monitored by the increase in absorbance at $560 \mathrm{~nm}$ in the a Gen $5^{\mathrm{TM}}$ spectrophotometer. A single unit of SOD was defined as the amount of enzyme necessary to inhibit NBT photoreduction by $50 \%$. The APX activity was determined through the method of NAKANO \& ASADA (1981). The reaction mixture was composed of potassium phosphate buffer $200 \mathrm{mM}(\mathrm{pH} 7.0)$, hydrogen peroxide $2 \mathrm{mM}$ and ascorbate acid $10 \mathrm{mM}$. The reaction was initiated by adding $10 \mu \mathrm{L}$ of leaf extract and the activity was measured through ascorbate oxidation at $290 \mathrm{~nm}$, during 3 minutes at $25^{\circ} \mathrm{C}$. The coefficient of molar extinction of $2.8 \mathrm{mM}^{-1} \mathrm{~cm}^{-1}$ (Nakano \& Asada, 1981) was used to calculate the APX activity $\left(\mathrm{mM} \mathrm{min} \mathrm{mg}^{-1}\right.$ of protein). The concentration of proteins in each sample was determined according to the colorimetric method described by BRADFORD (1976). All assays were replicated in triplicate.

\section{Experimental design and data analysis}

The experiment was conducted in a replicated (triplicate) randomized block design (RBD) with three treatments: plants sprayed with common $\mathrm{BE}$, black BE, or water (mock inoculation used as control) for the evaluation of enzyme activities. Data for the activity of POX, CAT, SOD, APX and PAL were analyzed using Analysis of variance (ANOVA) and the means compared with the Tukey post hoc test at $(\mathrm{P}<0.05)$. The analyses were realized using Sisvar software (version 5.3).

\section{RESULTS AND DISCUSSION}

In this research, the activity of some important enzymes responsible for removing the reactive oxygen species (ROS) during the infectious process of strains of $\boldsymbol{C}$. coffeicola in coffee leaves were determined.

Despite the strains being isolated from fields displaying different symptoms, both induced defense responses from the coffee plants.

The POX activity was significantly increased in the plants inoculated with black BE strain compared to non-inoculated plants at $12 \mathrm{hpi}$ and 24 hpi (Figure 1A). Plants inoculated with the commom $\mathrm{BE}$ also showed increased POX activity in relation to the non-inoculated plants at 24 hpi (Figure 1A). There was no difference between the treatments for the POX activities (at 36 hpi and 48 hpi (Figure 1A)) and CAT activities (at 12 hpi (Figure 1B)). Plants inoculated with the black BE strain showed increased CAT activity at $24 \mathrm{hpi}$ and $48 \mathrm{hpi}$ (Figure 1B). Noninoculated plants showed increased CAT activity at 36 hpi (Figure 1B). Plants inoculated with the common 


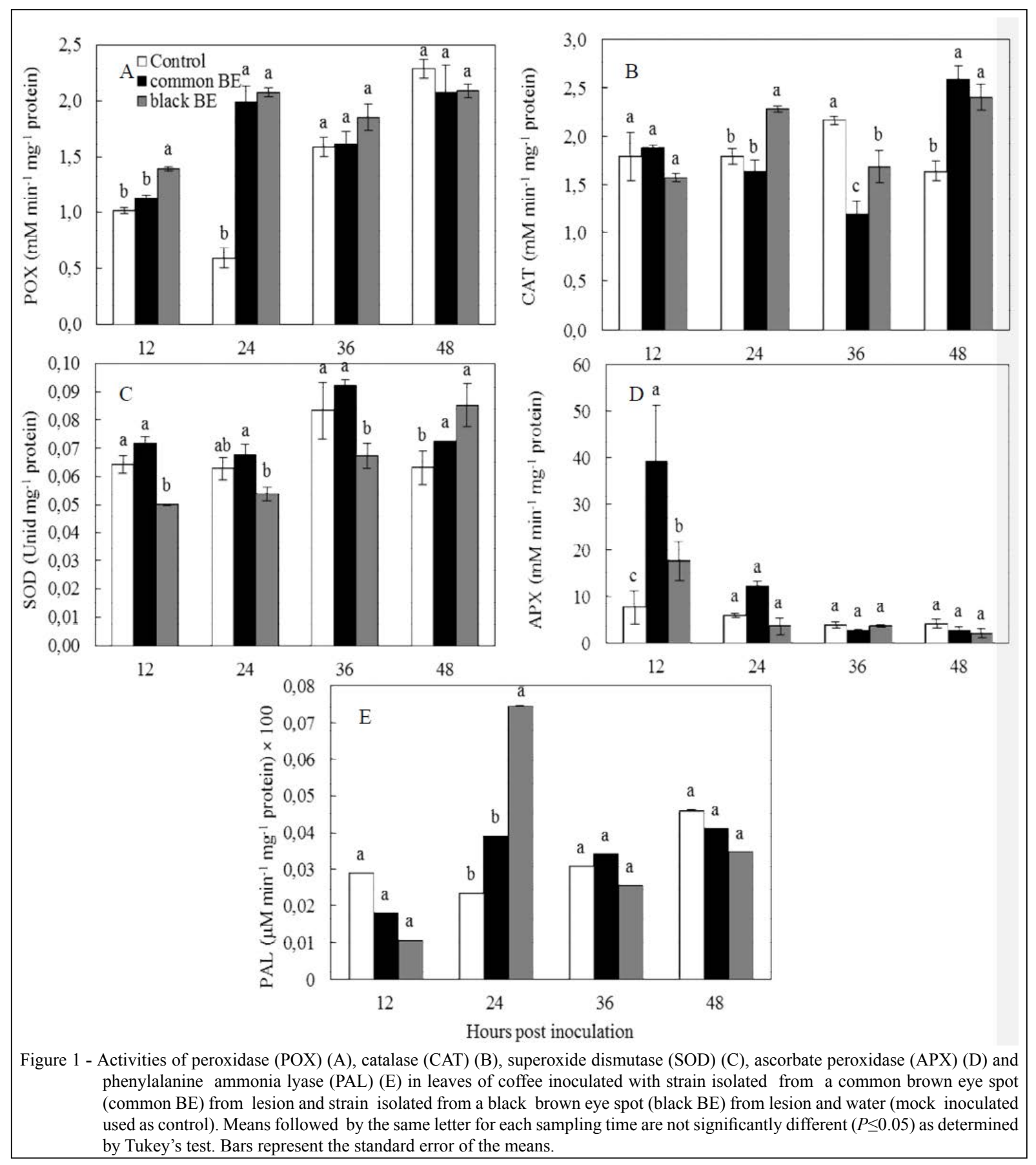

BE strain also presented increased CAT activity compared with non-inoculated plants at 48 hpi (Figure 1B). Non-inoculated and inoculated plants with the common BE had greater SOD activity at $12 \mathrm{hpi}$ and 36 hpi (Figure 1C). SOD activity was significantly increased in plants inoculated with both strains in comparison to non-inoculated ones at 48 hpi (Figure 1C). Inoculated plants with the common BE strain showed increase in the APX activity in comparison to non-inoculated plants at $12 \mathrm{hpi}$ (Figure 1D). There was no significant difference among the treatments for APX activity at 24, 36 and 48 hpi (Figure 1D). There was no significant difference among the treatments for PAL activity at 12, 36 and 48 hpi (Figure 1E). Plants inoculated with the black BE strain displayed increased PAL activity compared with the non-

Ciência Rural, v.46, n.10, out, 2016. 
inoculated and inoculated plants with the common $\mathrm{BE}$ strain at $24 \mathrm{hpi}$ (Figure 1E). In literature, there are a few accounts of alterations in the antioxidant metabolism of infected plants by Cercospora, mainly when it refers to strains that cause different symptoms in coffee plants (NASCIMENTO et al., 2014). When comparing the two $\boldsymbol{C}$. coffeicola strains (common BE and black BE), the results showed that both strains were able to induce the activity of enzymes in coffee leaves; however, there was variation in the timing of enzymes activation for each strain depending on the enzyme being analyzed. This is probably due to differences in the initial stages of penetration of both strains. The coffee plant recognized the strains in a similar way and was inhibited by $\mathrm{H}_{2} \mathrm{O}_{2}$ produced by the plant, which can be demonstrated through increased POX and APX activity in the first hours of infection. Similar results were reported by NASCIMENTO et al. (2014), who verified increased POX and PAL enzyme activity in inoculated soybean plants with Cercospora sojina. POX is a pathogenesis related protein and is induced in the host by the presence of pathogens (VAN LOON et al., 2006). Suberization of tissues, catabolism of auxins, strengthening of the cellular wall and responses of defense in plants are responsible for biosynthesis of lignin (HIRAGA et al., 2001 Conversely, PAL is the key enzyme in the phenylpropanoid pathway which is important in coffee plant defence responses. In this study, comparative analyses of PAL activity suggested phenylpropanoids as antioxidant compounds can be extremely important for the antioxidant system of the coffee tree infected with the black BE strain at $24 \mathrm{hpi}$. Similarly, GHOLIZDEH \& KOHNEHROUZ (2010) suggested that PAL could be the main component for the antioxidant system of corn under saline stress. In this study, the observed enzyme activity of POX, APX and PAL suggested that the $\boldsymbol{C}$. coffeicola strains likely develop in a similar way on dead plant cells without being inhibited by the accumulation of $\mathrm{H}_{2} \mathrm{O}_{2}$ to $\mathrm{O}_{2}^{-}$produced when the plants are infected by pathogens. This is possibly due to the fact that Cercospora produces cercosporin toxin that acts in the plasmatic membrane of the host cell, promoting cell death and release of ROS (DAUB et al., 2013). These results suggested that this toxin could have inhibited the defense mechanisms of the plants, thus permitting the fungus to have access to nutrients. The APX enzyme, participant of the ascorbateglutathione cycle, acts together with POX and CAT, removing $\mathrm{H}_{2} \mathrm{O}_{2}$ from plant cells. In the first reaction of catalyzation, APX uses two molecules of ascorbate to reduce $\mathrm{H}_{2} \mathrm{O}_{2}$ with concomitant generation of two molecules of malondialdehyde, the main product in lipid peroxidation of the cellular membranes (SHARMA et al., 2012). The accounts of this study agree with DEBONA et al. (2012), who verified increased APX activity in wheat plants inoculated with Pyricularia oryzae. DOMICIANO et al. (2015) also verified increased activities of these enzymes for the same pathosystem when plants were treated with silicon. In relation to CAT activity, this enzyme was greater in inoculated plants with the black BE strain, compared with non-inoculated plants at 36 hpi. In the same way, DEBONA et al. (2012) verified increased CAT activity in wheat plants inoculated with $\boldsymbol{P}$. oryzae compared to non-inoculated plants at $48 \mathrm{hpi}$. CAT catalyzes the dismutation of two molecules of $\mathrm{H}_{2} \mathrm{O}_{2}$ into water and oxygen (SHARMA et al., 2012). SOD activity increased in plants inoculated with both strains at $48 \mathrm{hpi}$, an observation likely to be associated with the beginning of colonization of coffee leaf tissues by the fungal strains. These results are similar to those observed by DEBONA et al. (2012), who reported increased SOD activity in plants inoculated with $\boldsymbol{P}$. oryzae, an increase in activity being related to the development of blast symptoms. According to BOLWELL et al. (2002), virulent pathogens can avoid or suppress the recognition of the host, only inducing the initial phase of defence responses. According to LEVINE et al. (1994), the current toxicity of the ROS in the interaction between the pathogen and host is going to depend on the sensitivity of the pathogen to the concentration of these radicals. Some fungi such as Botrytis cinerea and Cercospora can benefit from the increase of ROS generated against them in plant defence mechanisms, facilitating host colonization and absorption of nutrients through the exploitation of these host defence mechanisms (GOVRIN \& LEVINE, 2000).

In this study, it is speculated that the increased activity of these enzymes could be a strategy by the plant to restrict the colonization of both strains due to the removal of ROS. Despite having observed little differences in the enzymes action in the plants when inoculated with both strains, all the lesions observed in the greenhouse were of the common BE type.

Climate changes that are currently affecting coffee production around the world, mainly in South America (JHA et al., 2014) can have effects on the pathogen, disease development and on coffee production. These drastic changes in the environment could result in $\boldsymbol{C}$. coffeicola undergoing selection for new and more aggressive strains. The findings of this research indicated that there are other factors influencing the occurrence of black BE lesions in field conditions. 
Overall, studies about the infectious process of strains in different environmental and nutritional conditions, together with the confirmation and accurate identification of these strains causing different symptoms of brown eye spot is necessary through the use of molecular tools.

\section{CONCLUSION}

This study clearly demonstrated that both strains were able to induce alterations in the antioxidant metabolism of coffee leaves, suggesting that other factors leading to the black BE lesion type in field conditions are at play. Further investigation is needed to ascertain the cause of these differing symptoms.

\section{ACKNOWLEDGEMENTS}

To the Coordenação de Aperfeiçoamento de Pessoal de Nível Superior (CAPES) (for granting the scholarship, to Fundação de Amparo a Pesquisa do Estado de Minas Gerais (FAPEMIG) for giving support to the research group of the last author, CAG PPM-00248-13 and to Conselho Nacional de Desenvolvimento Científico e Tecnológico $(\mathrm{CNPq})$ for the productivity grants in research for the last two authors Mário Lúcio Vilela de Resende e Eduardo Alves. The authors Dra. Deila Magna Botelho dos Santos and Dr. Leônidas Leoni Belan for technical assistance.

\section{REFERENCES}

ANDERSON, D. et al. Changes in isozyme profiles of catalase, peroxidase and glutathione reductase during acclimation to chilling in mesocotyls of maize seedlings. Plant Physiology, v.109, p.1247-57, 1995. Available from: <http://www.ncbi.nlm.nih.gov/ pmc/articles/>. Accessed: Jun. 14, 2015.

BOLWELL, G.P. et al. The apoplastic oxidative burst in response to biotic stress in plants: a three-component system. Journal of Experimental Botany, v.53, p.1367-1376, 2002. Available from: $<$ http://dx.doi.org/10.1093/jexbot/53.372.1367>. Acessed: Jan. 10, 2015. doi: 10.1093/jexbot/53.372.1367.

BRADFORD, M.N. A rapid and sensitive method for the quantitation of microgram quantities of protein utilizing the principle of protein-dye binding. Analytical Biochemistry, v.72, p.248-254, 1976. Available from: <http://dx.doi. org/10.1006/abio.1976.9999>. Accessed: Jan. 12, 2015. doi: 10.1006/abio.1976.9999.

CAKMAK, L.; HORST, W.J. Effect of aluminium on lipid peroxidation, superoxide dismutase, catalase, and peroxide activities in root tips of soybean (Glycine max). Physiologia Plantarum, v.83, p.463-68, 1991. Available from: <http://dx.doi. org/10.1111/j.1399-3054.1991.tb00121.x>. Accessed: Jan. 12, 2015. doi: 10.1111/j.1399-3054.1991.tb00121.x.

CHANCE, B.; MAEHLEY, A.C. Assay of catalases and peroxidases. Methods in Enzymology, v.2, p.764-75, 1995. Available from: $<$ http://dx.doi.org/10.1016/s0076-6879(55)02300-8>. Accessed: Jan. 13, 2015. doi: 10.1016/s0076-6879(55)02300-8.
DAUB, M.E et al. Reactive oxygen species in plant pathogenesis: the role ofpPerylenequinone photosensitizers. Antioxidant \& Redox Signaling, v.19, p.970-989, 2013. Available from: <http:// dx.doi.org/10.1089/ars.2012.5080>. Accessed: Jan. 13, 2015. doi: 10.1089/ars.2012.5080.

DEBONA, D. et al. Biochemical changes in the leaves of wheat plants infected by Pyricularia oryzae. Phytopathology, v.102, p.1121-1129, 2012. Available from: <http://dx.doi. org/10.1094/phyto-06-12-0125-r>. Accessed: Dec. 10, 2014. doi: 10.1094/phyto-06-12-0125-r.

DOMICIANO, G.P. et al. Alterations in gas exchange and oxidative metabolism in rice leaves infected by Pyricularia oryzae are attenuated by silicon. Phytopathology, v.105, p.1-33, 2015. Available from: <http://dx.doi.org/10.1094/phyto-10-14-0280-r>. Accessed: Dec. 10, 2014. doi: 10.1094/phyto-10-14-0280-r.

GHOLIZADEH, A.; KOHNEHROUZ, B. Activation of phenylalanine ammonia lyase as a key component of the antioxidative system of salt-challenged maize leaves. Brazilian Journal of Plant Physiology, v.22, p.217-223, 2010. Available from: <http://dx.doi.org/10.1590/s167704202010000400001>. Accessed: Dec. 14, 2014. doi: 10.1590/ s1677-04202010000400001.

GOVRIN, E.M.; LEVINE, A. The hypersensitive response facilitates plant infection by the necrotrophic pathogen Botrytis cinerea. Current Biology, v.10, p.751-757, 2000. Available from: $<$ http://dx.doi.org/10.1016/s0960-9822(00)00560-1>. Accessed: Dec. 13, 2014. doi: 10.1016/s0960-9822(00)00560-1.

GUO, Y. et al. Use of silicon oxide and sodium silicate for controlling Trichothecium roseum postharvest rot in Chine cantaloupe (Cucumis melo L.). International Journal of Food Science \& Technology, v.42, p.1012-1018, 2007. Available from: $<$ http://dx.doi.org/10.1111/j.1365-2621.2006.01464.x>. Accessed: Apr. 02, 2016. doi: 10.1111/j.1365-2621.2006.01464.x.

HIRAGA, S. et al. A large family of class III plant peroxidases. Plant Cell Physiology, v.42, p.462-468, 2001. Available from: $<$ http://dx.doi.org/10.1093/pcp/pce061>. Accessed: Dec. 14, 2015. doi: $10.1093 / \mathrm{pcp} / \mathrm{pce} 061$.

JHA, S. et al. Shade coffee: update on a disappearing refuge for biodiversity. BioScience, v.64, p.416-428, 2014. Available from: <http://bioscience.oxfordjournals.org/content/ early/2014/04/14/biosci.biu038>. Accessed: Feb. 14, 2016. doi: 10.1093/biosci/biu038.

KAR, M.; MISHRA, D. Catalase, peroxidase and polyphenoloxidase activities during rice leaf senescence. Plant Physiology, v.57, p.315-319, 1976. Available from: $<$ http://dx.doi.org/10.1104/pp.57.2.315>. Accessed: Jan. 10, 2015. doi: 10.1104/pp.57.2.315.

LEVINE, A. et al. $\mathrm{H}_{2} \mathrm{O}_{2}$ from the oxidative burst orchestrates the plant hypersensitive disease resistance response. Cell, v.79, p.583-593, 1994. Available from: <http://dx.doi. org/10.1016/0092-8674(94)90544-4>. Accessed: Feb. 12, 2015. doi: 10.1016/0092-8674(94)90544-4.

LIMA, L.M. et al. Relationship between incidence of brown eyespot of coffee cherries and the chemical composition of coffee beans. Journal of Phytopathology, v.160, p.209-211, 2012. Available from: <http://onlinelibrary.wiley.com/doi/10.1111/ 
j.1439-0434.2012.01879.x/abstract>. Accessed: May 22, 2016. doi: 10.1111/j.1439-0434.2012.01879.x.

MATIELLO, J.B.;ALMEIDA, S.R. (2013). Cercospora negra associada à deficiência de fósforo em cafeeiros. Procafé online. Available from: $<$ http://www.fundacaoprocafe.com.br>. Accessed: July, 29, 2014.

NAKANO, Y.; ASADA, K. Hydrogen peroxide is scavenged by ascorbate-specific peroxidase in spinach chloroplasts. Plant \& Cell Physiology, v.22, p.867-80, 1981. Available from: <http://pcp.oxfordjournals.org/content/22/5/867>. Accessed: Mar. 20, 2015.

NASCIMENTO, K.J.T. et al. Soybean resistance to Cercospora sojina infection is reduced by silicon. Biochemistry and Cell Biology, v.104, p.1183-1191, 2014. Available from: $<$ http://dx.doi. org/10.1094/phyto-02-14-0047-r>. Accessed: Mar. 20, 2015. doi: 10.1094/phyto-02-14-0047-r.

NELSON, S.C. Cercospora leaf spot and berry blotch of coffee. University of Hawaii: Cooperative Extension Service, 2008. Available from: <http://www.ctahr.hawaii.edu/site/Info.aspx $>$. Accessed: May. 22, 2016.

SCANDALIOS, J.G. Oxidative stress: molecular perception and transduction of signals triggering antioxidant gene defenses. Brazilian Journal of Medical and Biological Research, v.38, p.995-1014, 2005. Available from: <http://dx.doi.org/10.1590/ s0100-879x2005000700003>. Accessed: Jun. 20, 2014. doi: 10.1590/s0100-879x2005000700003.

SHARMA, P. et al. Reactive oxygen species, oxidative damage, and antioxidative defense mechanism in plants under stressful conditions. Journal of Botany, v.1, p.1-26, 2012. Available from: $<$ http://dx.doi.org/10.1155/2012/217037>. Accessed: Jan. 30, 2015. doi: $10.1155 / 2012 / 217037$.

SOUZA, A.G.C. et al. Infection process of Cercospora coffeicola on coffee leaf. Journal of Phytopathology, v.159, p.6-11, 2011. Available from: <http://dx.doi. org/10.1111/j.1439-0434.2010.01710.x>. Accessed: Feb. 23, 2015. doi: $10.1111 / \mathrm{j} .1439-0434.2010 .01710 . x$.

VAN LOON, L.C. et al. Significance of inducible defence-related proteins in infected plants. Annual Review of Phytopathology, v.44, p.135-162, 2006. Available from: <http://dx.doi.org/10.1146/ annurev.phyto.44.070505.143425>. Accessed: July 16, 2014. doi: 10.1146/annurev.phyto.44.070.

ZUCKER, M. Induction of phenylalanine deaminase by light and its relation to chlorogenic acid synthesis in potato tuber tissue. Plant Physiology, v.40, p.779-784, 1965. Available from: <http:// dx.doi.org/10.1104/pp.40.5.779>. Accessed: Jun. 15, 2015. doi: 10.1104/pp.40.5.779. 